\title{
Development of Highly Accurate Analysis Method for Compressible Fluid Considering Radiation and Ablation
}

\author{
Makoto Koizumi Member (Hitachi, Ltd. Power \& Industrial Systems R\&D Labs.) \\ Hajime Urai Member (Hitachi, Ltd. Power \& Industrial Systems R\&D Labs.) \\ Youichi Osita Member (Hitachi, Ltd. Power \& Industrial Systems R\&D Labs.) \\ Naoki Osawa Member (Hitachi, Ltd. Power \& Industrial Systems R\&D Labs.) \\ Masanori Tukushi Member (Japan AE Power Systems Corporation) \\ Noriyuki Yaginuma Member (Japan AE Power Systems Corporation)
}

Keywords: gas circuit breaker, arc, radiation, ablation, compressible fluid dynamics

To understand physical phenomena in gas circuit breaker, we developed a highly accurate analysis method for compressible fluid considering arc behavior. The analysis method is based on CIP (Constrain of Interpolation Profile) method. To calculate arc behavior, we improved the method as follows;

(1) A large change of density and energy in arc causes numerical oscillation in case of conventional CIP method. To suppress this problem, the product of density and internal energy is treated as unknown valuable of transport energy equation solved by CIP method.

(2) To consider the effect of ablation of nozzle wall the rate of evaporation is assumed to be proportion to the difference between the power emission rate from wall and the intensity of radiation in the space.

(3) To solve linear equation systems appeared in pressure, electric and radiation fields, we have improved PCG (Preconditioned Conjugate Gradient) method by reduction of unknowns. In order to reduce number of unknowns, one step Gaussian elimination is applied to the coefficient matrices.

We have applied the method to an ablation measurement test stand and an interrupter model of gas circuit breaker, and confirmed the calculation results agree with the experimental ones. Comparison of measurements and calculation results of puffer pressures of the interrupter model of gas circuit breaker are illustrated in Fig. 1. And arc voltages are also shown in Fig. 2. The calculation results of puffer pressure agreed the lower envelope of measured ones as shown in Fig. 1. And calculation results of arc voltage are also coincide with experimental ones exclude near current zero point.

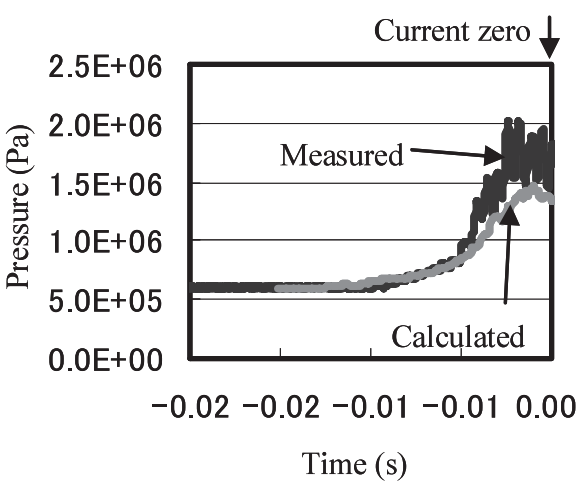

Fig. 1. Change of pressure in puffer room

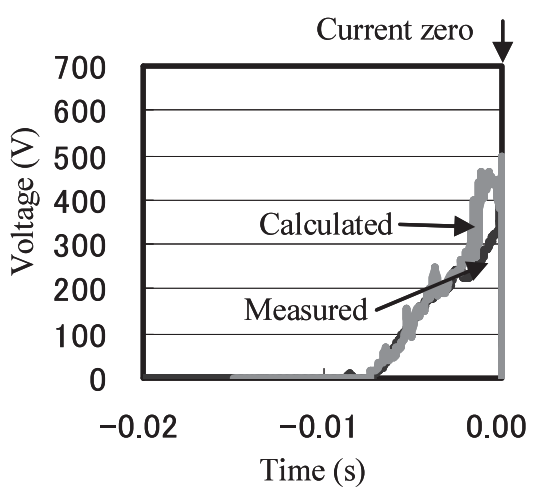

Fig. 2. Change of arc voltage 


\title{
輻射とアブレーションを考慮した高精度気流解析技術の開発
}

\author{
正員 小泉 真* 正員 浦井 一* \\ 正 員 大下 陽一* 正 員 大澤 直樹* \\ 正 員 筑紫 正範** 正 員 柳沼 宣幸**
}

\section{Development of Highly Accurate Analysis Method for Compressible Fluid Considering Radiation and Ablation}

Makoto Koizumi*, Member, Hajime Urai*, Member, Youichi Osita*, Member, Naoki Osawa*, Member, Masanori Tukushi**, Member, Noriyuki Yaginuma**, Member

To understand physical phenomena in gas circuit breaker, we developed a highly accurate analysis method for compressible fluid considering arc behavior. The feature of the method is as follows, (1) To suppress numerical oscillation, the product of density and internal energy is treated as unknown valuable of transport energy equation solved by CIP (Constrain of Interpolation Profile) method. (2) To consider the effect of ablation of nozzle wall the rate of evaporation is assumed to be proportion to the difference between the power emission rate of wall and the intensity of radiation in the space. (3) To solve linear equation systems appeared in pressure, electric and radiation fields, we have improved PCG (Preconditioned Conjugate Gradient) method by reduction of unknowns. We have applied the method to an ablation measurement test stand and an interrupter model of gas circuit breaker, and confirmed the calculation results agree with the experimental ones.

キーワード：ガス遮断器, アーク, 輻射, アブレーション, 気流解析

Keywords: gas circuit breaker, arc, radiation, ablation, compressible fluid dynamics

\section{1. 前 書き}

遮断器内の気流解析技術としては FLIC（FLuid In Cell） 法 ${ }^{(1)}$ TVD (Total Variation Diminishing) 法 ${ }^{(2)}$ 及び CIP (Constrain of Interpolation Profile) 法 ${ }^{(3)}$ による解析等幾つ かの方法が提案されている。また，近年では市販プログラ ムがかなり充実しており，それを用いた方法なども提案 ${ }^{(4)}$ されている。これらの方法のうち, FLIC 法や TVD 法では, コントロールヴォリュームを用いた保存型で記述されてお り, メッシュ分割が適切であれば高精度で解析できる。し かし，構造物に適合したメッシュ分割では，メッシュ形状 が正三角形から大きくずれることがあり，この場合解析精 度が悪化する。また，時間方向については陽的に解くため, 時間ステップが音速によって制限され，計算時間が掛かる

\footnotetext{
*（株）日立製作所電力・電機開発研究所

厂 319-1221 日立市大みか町 7-2-1

Hitachi, Ltd. Power \& Industrial Systems R\&D Labs.

7-2-1, Omika-cho, Hitachi 319-1221

**(株) 日本 $\mathrm{AE}$ パワーシステムズ

于316-8501 日立市国分町 1-1-1

Japan AE Power Systems Corporation

1-1-1, Kokubu-cho, Hitachi 316-8501
}

問題があった。これらを陰的に解く方法もあるが，クーラ ン数が 1 を超えるような時間ステップで解くと数值粘性の ため, やはり精度が悪化する問題がある。これに対し, CIP 法は直交メッシュと組み合わせて解くため, 比較的高精度 が維持でき, また, 解法も準陰解法であるため, 流速のクー ラン数による時間ステップの制限をうけるが, 音速による 制限は受けない。このため, 時間ステップがむやみには細 かくならないことが期待される。そこで, 本報告では CIP 法を取り上げる。

従来の CIP 法 ${ }^{(5)}$ では, 非保存形で方程式が記述されてお り,アーク解析のように高温でのガス分子の解離・結合に伴 うガス定数の変動を伴う場合, 精度が保てない問題があっ た。また, アークを解く場合, 流体を解くときに必要な圧 力方程式を解く以外にも, 輻射場, 及び, 電場を解くため に連立方程式を解く必要がある。連立方程式を解く方法と しては PCG (Preconditioned Conjugated Gradient) 法 ${ }^{(6)}$ 用いるがやはりできるだけ収束が早い方が繰り返し計算に は都合が良い。本報告では，これについても改良を行った ので報告する。

ところで，高温ガスを取り扱う場合，熱輻射を考慮する 必要があるが，その取り扱い方は著者らが先に報告した方 
法 (2)を含めて, 幾つか報告されている。しかし, アブレー ションを考慮する方法については幾つか報告(7)はあるが, 空間の輻射強度と壁面からの射出能を結びつけたものは著 者らが先に報告 ${ }^{(8)}$ したもの以外にはあまりない。そこで, 本報告ではこれらの内容もまとめて報告する。

\section{2. 解析モデル}

〈2・1〉 基 礎 式 基礎方程式は圧縮性のナビアストー クス方程式と, 輻射場の方程式, 及び電流場の方程式であ る。電磁力についは，影響が小さいのでここでは考慮しな い。状態方程式は高温での $\mathrm{SF}_{6}$ の分解再結合を考慮して温 度・圧力を独立変数として求めテーブル化した。導電率・比 熱などの物性值についても電子状態を考慮して温度 · 圧力 の関数として予め求めておき同様にテーブル化した。(1) (3) 式に圧縮性のナビアストークス方程式を示す。 連続の式 :

$$
\rho,{ }_{t}+(\mathbf{u} \cdot \operatorname{grad}) \rho=-\rho \cdot \operatorname{div} \mathbf{u}
$$

運動方程式：

$$
\mathbf{u}, t+(\mathbf{u} \cdot \operatorname{grad}) \mathbf{u}=-\operatorname{grad} p / \rho+\mathbf{F} / \rho
$$

エネルギー方程式：

$$
E_{,}+(\mathbf{u} \cdot \operatorname{grad}) E=(Q-p \cdot \operatorname{div} \mathbf{u}) / \rho
$$

ここで, $\rho$ は密度, $\mathbf{u}$ は速度べクトル,$p$ は圧力, $s$ は蒸発などの湧き出し, $\mathbf{F}$ は粘性摩擦をも含めた 体積力, $E$ は単位質量当りの内部エネルギー, $Q$ は粘性発熱を含めた発熱密度を現す。添え字のコ ンマは微分を表し， $t$ は時間を表す。

アークからの輻射は次のように取り扱う。輻射吸収性の ガス内での輻射強度 $U$ は次のヘルムホルッ方程式を満た す ${ }^{(2)}$ 。

$$
\operatorname{div}\left\{\operatorname{grad} U /\left(3 k_{r}\right)\right\}=k_{p} U-E_{c}
$$

ここで， $E_{c}$ はガスの輻射エネルギー射出率， $k_{p}, k_{r}$ はそれ ぞれ Plank 平均と Rossland 平均による吸収係数である ${ }^{(2)}$ 。 また, Ec はステファンボルツマン定数 $\sigma_{s}$ を用いて次のよ うに表せる。

$$
E_{c}=4 k_{p} \sigma_{s} T^{4}
$$

ここで，Tはガスの温度である。

アーク中の電流分布は次のように取り扱う。アーク中及 び周囲のガス中の電圧を $\phi$ とすると，ガスを含めた導電率 $\sigma$ を用いて，電場を支配する方程式は次のようになる。

$$
\operatorname{div}\{\sigma \cdot \operatorname{grad} \phi\}=0
$$

ここで, 導電率は温度の関数である。低温のガスの導電率 は非常に小さいものであるが，マトリックスの収束性を考 えて $\sigma=10^{-7} \mathrm{~S} / \mathrm{m}$ 程度とする。また, 誘電体の導電率も
同様に小さいものであるが，導電率が小さい場合，電場分 布は遮断現象のように速い現象では誘電率によって決まる。 そこで, ここでは, 誘電体については実際の導電率は無視 して，誘電率の比に従って導電率があると仮定する。こう することによりノズルなどの誘電体を含めた電場解析が模 擬できる。(6) 式を解くことにより電流によるジュール発熱 を計算できる。輻射損失とジュール発熱をあわせたものを (3) 式の発熱密度として下式により計算する。

$$
Q=\sigma(\operatorname{grad} \phi)^{2}+k_{p} U-E_{c}+Q_{\tau} .
$$

ここで， $Q_{\tau}$ は粘性発熱を示す。

〈2·2〉 離 散 化離散化には移流項での物理量の分 布形状を保つために, 物理量の勾配の移流も考慮した, CIP 法を用いる。特に, 圧力を陰的に求める CCUP 法で離散化 する。CIP 法による離散化方法の詳細は文献(5) を参照さ れたし。従来の CCUP 法では移流項を取り扱う際, (1) (3) 式の物理量をそのまま取り扱っていた。しかし，この形 式で風上差分により離散化すると次のような不都合が生じ る。セル内において, 内部エネルギー $E$ の分布に大きな差 があると, 内挿時に誤差を生じる。この誤差は, 時間積分 に伴う繰り返し計算を重ねると蓄積することが予想される。 そこで, (3) 式の代わりに, 密度を内部エネルギーに乗じた 值, 即ち, 単位体積当りの内部エネルギー $e$ を用いる。こ の場合, エネルギーの輸送方程式は次のように変換される。

$$
e,{ }_{t}+(\mathbf{u} \cdot \operatorname{grad}) e=Q-(p+e) \operatorname{div} \mathbf{u}
$$

こうすると, 次のような利点がある。理想気体では, 密度 $\rho$ は絶対温度に逆比例するのに対し, $E$ は絶対温度に比例 する。実在気体では厳密にはこのような関係は成り立たな いが，近似的にはこのような相関関係がある。そのため，e は温度変化の影響を受けにくくなる。これにより，七ル内 の $e$ の変化が小さくなり, 風上差分による内挿誤差を減少 できるものと期待できる。

(8) 式の左辺および $Q$ を用いて, 風上差分を実施した後 の值を $e *$ とする。残りの補正は次のようになる。

$$
\frac{e^{n+1}-e^{*}}{\delta t}=-\left(p+e^{*}\right) \operatorname{div} \mathbf{u}^{n+1}
$$

ここで, $\delta t$ は時間増分である。上付き添え字 $n+1$ は次の 時刻での值である。オリジナルの CIP 法では, (9) 式の右 辺には, $e^{*}$ の項が無いが, 未知数の変換に伴い, 付加され たものである。上式において, div $\mathbf{u}^{n+1}$ はまだ, 未知のまま であるが，これは，従来の方法で解くことができる。即ち， 風上差分実行後の, 密度を $\rho^{*}$, 流速を $\mathbf{u}^{*}$ として, 密度, 流 速に対する補正式は，次のように表せる。

$$
\begin{aligned}
& \rho^{n+1}=\rho^{*}-\rho^{*} \delta t \operatorname{div} \mathbf{u}^{n+1} . \\
& \mathbf{u}^{n+1}=\mathbf{u}^{*}-\frac{\delta t}{\rho^{*}} \operatorname{grad} p^{n+1}
\end{aligned}
$$

風上差分計算後の補正は等エントロピー的に行われると 考えると, 圧力変化は次のようになる。ここでは, 精度を 
上げるため， 2 次のオーダーまで取る。

$$
\begin{aligned}
\Delta p & =\left[\frac{\partial p}{\partial \rho}\right]_{s} \delta \rho+\frac{1}{2}\left[\frac{\partial^{2} p}{\partial \rho^{2}}\right]_{S} \delta \rho^{2} \\
& =C s^{2}\left(1+\frac{1}{2 \rho}(\gamma-1) \delta \rho\right) \delta \rho
\end{aligned}
$$

ここで, $\gamma$ は比熱比で, $C s$ は音速を表す。上式の圧力差 $\Delta p$ は次の時刻 $n+1$ と風上差分計算後の值との差を考えると次 のようになる。また，上式の添え字の $s$ は等エントロピー 変化を示す。

$$
\Delta p=p^{n+1}-p^{*}
$$

(12) 式に (13) 式を代入して, $\delta \rho=\rho^{n+1}-\rho^{*}$ を考慮して (10) 式を代入すると最終的に次の圧力に関する波動方程式 を得る。

$$
\begin{aligned}
& \frac{p^{n+1}-p^{*}}{C s^{2} \rho^{*}\left(1-\frac{1}{2}(\gamma-1) \delta t \operatorname{div} \mathbf{u}^{*}\right)} \\
& =-\delta t \operatorname{div} \mathbf{u}^{*}+\operatorname{div} \frac{\delta t^{2}}{\rho^{*}} \operatorname{grad} p^{n+1} \ldots \ldots \ldots \ldots \ldots
\end{aligned}
$$

(14) 式を解くことにより次のステップの圧力分布 $p^{n+1}$ が 得られる。次に, 得られた圧力分布より, $\delta t \operatorname{div} \mathbf{u}^{n+1}$ を計算 する。

$$
\delta t \operatorname{div} \mathbf{u}^{n+1}=-\frac{p^{n+1}-p^{*}}{C s^{2} \rho^{*}\left(1-\frac{1}{2}(\gamma-1) \delta t \cdot \operatorname{div} \mathbf{u}^{*}\right)}
$$

これを，(9)，(10) 式に代入し，次のステップの内部エネル ギー及び密度を計算する。また, 次のステップの流速は (11) 式に圧力 $p^{n+1}$ を直接代入して計算する。従来, (9), (10) 式 の $\operatorname{div} \mathbf{u}^{n+1}$ の計算は (11) 式より流速を求めてから計算して いたが，従来法だと，一旦流速を求めるため，計算誤差が 混入する可能性がある。そこで, div $\mathbf{u}^{n+1}$ を流速から求め ずに (15) 式の圧力から計算する方法とした。

(4) 式及び (6) 式は通常の直交差分法で離散化した。この 場合境界形状が問題になるが，差分格子を作る際，セル内 の物体と気体の占有率を考慮して，そのセルの物性值を決 める方法とした。流速及び体積占有率の定義点はセルの頂 点, 圧力, 熱エネルギー, 密度, 電圧及び温度はセル中心 においた。

CIP 法では風上差分を計算する際，三次の内挿関数を用 いて計算する。一般的に風上差分を計算する際，1次の内 挿関数を用いるとオーバーシュートやアンダーシュートが 起きず，安定に計算できることが知られている。しかし，1 次関数では内挿の繰り返しによる数值拡散が大きいことか ら，最近の流体計算では，あまり用いられなくなった。代 わりに, 高次 (特に 3 次) 内挿関数を用いて計算する手法 がとられている。この場合，数值拡散は小さくなるが，変 化の大きい問題を取り扱う場合，オーバーシュートやアン
ダーシュートがおき，計算が安定しない。そこで，圧縮性 の気流解析では数值的な制限を課して計算する方法 (TVD 法）や，人工的な数值粘性を入れる方法が開発されている。 これに対し，CIP 法では，有理関数を用いて，上記現象を 緩和する方法が提案されている ${ }^{(9)}$ 。この方法は有効と考え られるが，やはり十分には上記現象を抑制せず振動が残る。 そこで，ここでは，比較的単純な制限值関数を導入する。 それは, セル内の内挿值はセルの各端点の值を越えないと する方法である。風上差分を実行する際, 密度, 熱エネル ギー, 運動量について, 発生や消滅が無いとして計算する ため，七ル内では最大值原理が成り立つと仮定する。しか し，エネルギー及び, 密度がそれぞれ別々に上記条件を満た すように計算すると，数值的なずれが生じる。そこで，密 度, 熱エネルギーのどちらかが, 最大值を超えた場合, 次 のように計算する。

（i）密度の内挿值が各セルの頂点の最大值を超える場 合, 密度は最大值とする。このとき, 熱エネルギーは密度 が最大となるセル頂点の值とする。

（ii）密度の内挿值が最小值を下回る場合，密度は最小 值とする。このとき, 熱エネルギーは密度が最小となるセ ル頂点の值とする。

(iii) 熱エネルギーの内挿值が各セルの頂点の最大值を 超える場合, 熱エネルギーは最大值とする。このとき, 密 度は熱エネルギーが最大となるセル頂点の值とする。

(iv) 熱エネルギーの内挿值が各セルの頂点の最小值を 下回る場合，熱エネルギーは最小值とする。このとき，密 度は熱エネルギーが最小となるセル頂点の值とする。

こうすることにより, 密度と熱エネルギーの同時性が保 たれる。

〈2·3〉 アブレーションの取り扱い アーク近傍のノ ズル材料は輻射を吸収して蒸発すると考えられる。(4) 式の 右辺はガスが吸収する輻射エネルギーである。そこで，蒸 発量を見積もる場合についてもこの考え方を踏襲する。(4) 及び (5) 式では輻射吸収係数の一つである $k_{p}$ が含まれてい る。これは, ガス固有の輻射吸収係数 $k_{n}$ の関数となってい る(2)。

そこで，ノズル材の輻射吸収係数がガスの場合の $\theta$ 倍と すると，輻射場からノズル材が受け取るエネルギー $Q_{e v}$ は 壁面の輻射エネルギー射出率と空間での輻射強度の差に比 例するとして次式のように表せる。

$$
Q_{e v}=\theta k_{p}\left(U-4 \sigma T_{w}^{4}\right)
$$

$T_{w}$ は壁面の蒸発開始温度 (昇華温度) である。これに伴い, 蒸発量 $\delta W$ は蒸発潜熱 $L_{w}$ を用いて

$$
\delta W=Q_{e v} / L_{w}
$$

となる。(16) 式は単位体積当たりの熱吸収量を表すので (17) 式もやはり単位体積当たりの質量変化を示す。即ち, 単位 時間当たりのガス密度増加分を示す。また，このとき，内 部エネルギーもガスに持ち込まれる。その大きさは $T_{w}$ の 
温度でのガス状になった壁面材料の内部エネルギーである。 （蒸発潜熱はガス状態での内部エネルギーと固体状態での内 部エネルギーの差であり, 蒸発の際の体積膨張仕事に相当 する。）この，内部エネルギーは温度 $T_{w}$ での $\mathrm{SF}_{6}$ の内部工 ネルギーで代用する。その結果, 密度, 内部エネルギーの 変化は次のようになる。

$$
\begin{aligned}
& \rho^{* *}=\rho^{*}+\delta W \delta t \cdots \ldots \ldots \\
& e^{* *}=e^{*}+E\left(T_{w}, p_{w}\right) \delta W \delta t .
\end{aligned}
$$

ここで, $E\left(T_{w}, p_{w}\right)$ は壁温 $T_{w}$ 及び壁面での圧力 $p_{w}$ のとき の単位質量当りの内部エネルギーである。また, アスタリ スク*は変更前の值, 2 重のアスタリスク ${ }^{* *}$ は変更後の值 である。

$\langle\mathbf{2} \cdot \mathbf{4}\rangle$ 行列解法の改良行列解法には, 後氏の発案 した反復法 PCGPME (Preconditioned multiply Conjugated Gradient Polynomial Minimized method for finite Element method) (6) に改良を加えて用いている。PCGPMEは従来法 のなかで，収束が最も早い方法の一つである。時間ステッ プを更新する毎に解く連立方程式は，電界，輻射，及び圧 力方程式の三つである。このうち，アーク解析において， 電界と輻射を解くのに多くの反復時間を割いている。そこ で，反復時間を減らす方法を検討した。通常反復回数が増 える要因としては主に, 解くべき未知数の数が多くなるこ と, 及び行列の条件数（最大固有值と最小固有值の比）が 悪くなることによる。後者については，不完全 LU 分解に よる前処理法がすでにPCGPMEには組み込まれていて解 決済みである。そこで，前者の未知数を減らす方法を考え る。基本的なアイデアは未知数のうち幾つかについて予め 消去して, 方程式から取り除き, 方程式を解いた後, 取り 除いた未知数を基の方程式から求めるという，比較的古典 的な方法である。以下にその手順を示す。

電場, 輻射場, 及び圧力場の方程式は連立方程式となっ ている。これらの方程式を $\phi_{n}$ を未知数として次のように 書く。

$$
\sum_{m} A_{n m} \phi_{m}+D_{n} \phi_{n}=B_{n}
$$

ここで，A は行列の非対角項， $D$ は対角項を表し， $B$ は右 辺のベクトルを表す。(20) 式はゼロの多い行列となってい る。そのため, 上式の一部を消去すると未知数が減少する ため, 反復解法で解く場合, 早く収束するようになる。行 列の一部を消去する分解操作をガウスの掃出し法と同じよ うに行う。ただし，分解操作は一段階のみとし，また，分 解の中心となる軸（消去対象となる未知数が対角に来る方 程式）は図 1 に示す様に分解操作が互いに干渉しないよう に選ぶ。

まず，(20) 式を対角成分で割って規格化する。

$$
\sum_{m} A_{n m}^{\prime} \phi_{m}+\phi_{n}=B_{n}^{\prime}
$$

今, $\mathrm{n}$ 番目の未知数を消去することを考える。未知数 $\phi_{n}$ を

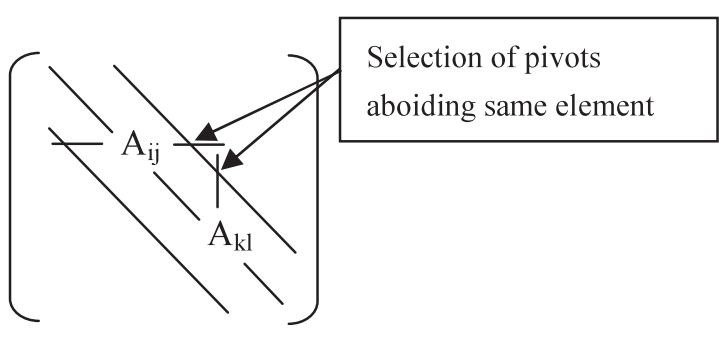

図 1 分解の軸の選択方法（実線は非 0 要素）

Fig. 1. Selection of pivots for decomposition of matrix.

含む n’ 番目の方程式は次のように書ける。

$$
\sum_{m \neq n} A_{n^{\prime} m}^{\prime} \phi_{m}+A_{n^{\prime} n}^{\prime} \phi_{n}+\phi_{n^{\prime}}=B_{n^{\prime}}^{\prime}
$$

上式から $\phi_{n}$ を消去すると次のようになる。

$$
\sum_{m \neq n} A_{n^{\prime} m}^{\prime} \phi_{m}-A_{n^{\prime} n}^{\prime} \sum_{m} A_{n m}^{\prime} \phi_{m}+\phi_{n^{\prime}}=B_{n^{\prime}}^{\prime}-A_{n^{\prime} n}^{\prime} B_{n}^{\prime}
$$

上式から $\phi_{n^{\prime}}$ を取り出して纏めて書くと次のようになる。

$$
\sum_{m \neq n}\left(A_{n^{\prime} m}^{\prime}-A_{n^{\prime} n}^{\prime} A_{n m}^{\prime}\right) \phi_{m}+\left(1-A_{n^{\prime} n}^{\prime} A_{n n^{\prime}}^{\prime}\right) \phi_{n^{\prime}}=B_{n^{\prime}}^{\prime}-A_{n^{\prime} n}^{\prime} B_{n}^{\prime}
$$

同様に未知数 $\phi \mathrm{n}$ を含む $\mathrm{n}$ 番目以外の方程式についても $\phi_{n}$ を消去する。 $\mathrm{n}$ 番目についてはこの操作を行わない。こう すると, 分解操作を行う方程式と行わない方程式の二組に分 けられる。ただし，ディリクレ境界条件を与える方程式は この操作を行わない。全未知数の数を $\mathrm{N}$, 分解操作を行っ た方程式の数を N'とすると, 未知数の数は N から N'に減 少する。この N' 個の方程式を反復法で解く事により解が 求まる。残りの未知数は求めた解とこの操作を行わなかっ た下記の (N-N') 個の方程式より求めることが出来る。

$$
\phi_{n}=B_{n}^{\prime}-\sum_{m} A_{n m}^{\prime} \phi_{m}
$$

この方法によると, 上記の処理はほぼ一つ置きの方程式に ついて実行されるので, 未知数の数はほぼ半減する。ただ し, バンド幅は逆に 2 倍程度増える。従ってメモリー的に はあまり効果はないが, 未知数が減る分だけ反復回数が減 少し計算が速くなる。

本行列解法の有効性を見るため試計算を行った。対象に した方程式は下記のポアソン方程式を直交差分で離散化し たものである。

$$
\left\{\phi_{i-1 j}+\phi_{i+1 j}-2 \phi_{i j}\right\} / \Delta x^{2}+\left\{\phi_{i j-1}+\phi_{i j+1}-2 \phi_{i j}\right\} / \Delta y^{2}=Q_{i j}
$$

境界条件はディリクレ条件として正方形領域の周囲を $\phi=0$ に固定した。また， $\Delta x$ 及び $\Delta y$ は 0.1 とし，分割数はそれ ぞれの方向に 300 とした。 $Q_{i j}$ は 1.0 と領域内を一定とし た。誤差評価には反復毎に各連立方程式の残差の二乗和を 右辺の二乗和で規格化して平方根を取ったノルムを用いた。 図 2 に収束状況を示す。改良版ではオリジナルの PCGPME より約 2 倍早く解が収束している。 


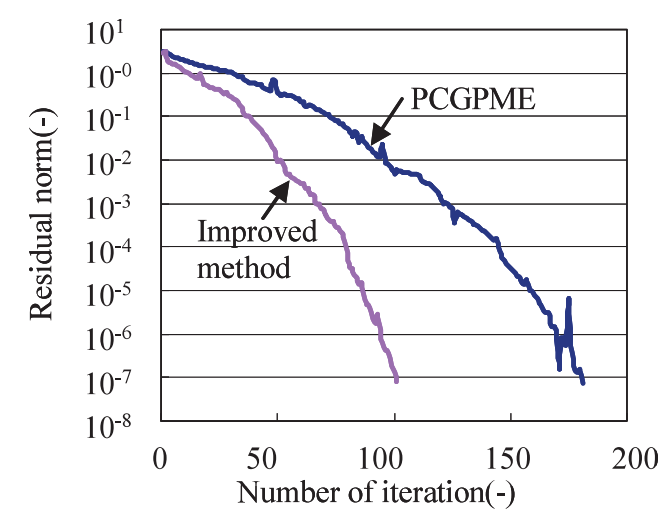

図 2 PCGPME 法の収束状況

Fig. 2. Convergence of PCGPME method.

\section{3. 解析結果}

〈3・1〉 アブレーション測定試験との比較 上述した 解析をノズル材アブレーション測定試験について実施し, 実測結果と比較した。図 3 に試験装置のノズル材試験部の 形状を示す。試験部には 2 つアーク電極を $15 \mathrm{~mm}$ の間 隔で対抗して設置し，その周りを取り囲むようにノズル材 試験片を配置した。圧力センサは試験片中央部に取付けた。 この試験部を， $\mathrm{SF}_{6}$ ガス $0.3 \mathrm{MPa}$ を封入した試験容器内に 配置し，ピーク值 $15 \mathrm{kA}$ の電流を通電した。使用したノズ ル材料は四フッ化エチレンである。

図 4 は通電開始から $6 \mathrm{~ms}$ 後の圧力分布の解析結果であ り, (a) はアブレーションを考慮しない場合，(b)はアブレー ションを考慮した場合である。(16) 式の比例定数 $\theta$ は壁面 での輻射の吸収率を示しており，実測に合うように調整し たところ $\mathrm{SF}_{6}$ の約 160 倍となった。図 4(a) に示すように, アブレーションの無い場合には通電開始直後にはアーク内 部にあるガスを加熱することによる圧力上昇はあるが，こ の期間を過ぎるとベース圧力 $(0.3 \mathrm{MPa})$ とほとんど変わら ない。これに対し，アブレーションを考慮すると，ノズル材 料蒸発によりアーク近傍にガスが供給されるため，図 4(b) に示すように最大 $1.54 \mathrm{MPa}$ 程度まで上昇する。

図 5 および図 6 は，試験片表面における圧力変化および アーク電圧の, 解析と実測との比較である。このときの測

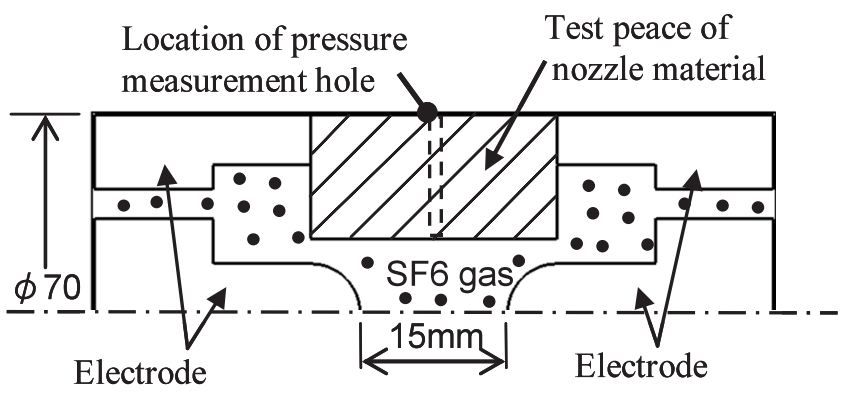

図 3 アブレーション測定試験装置

Fig. 3. Ablation measurement test part.

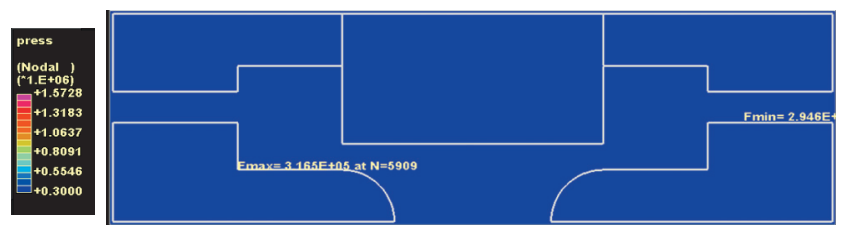

(a) Considering no ablation

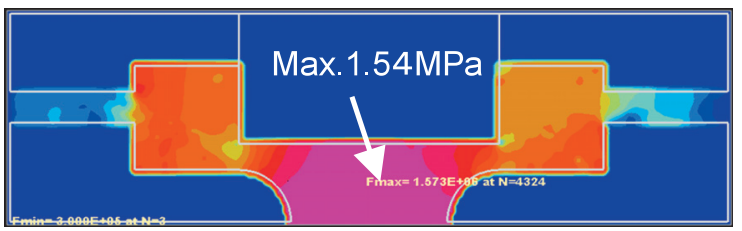

(b) Considering ablation

図 4 解析による通電開始後 $6 \mathrm{~ms}$ 後の圧力分布

Fig. 4. Calculated pressure distribution $6 \mathrm{~ms}$ after ignition of arc.

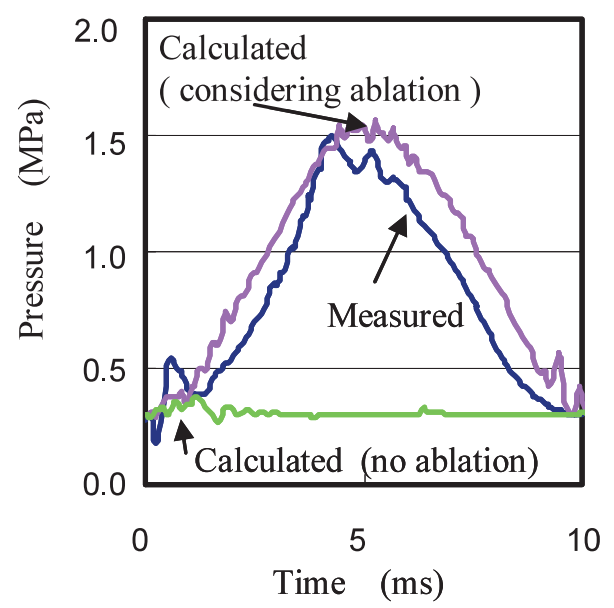

図 5 圧力変化の解析と実測との比較

Fig. 5. Comparison of calculated pressure with measured.

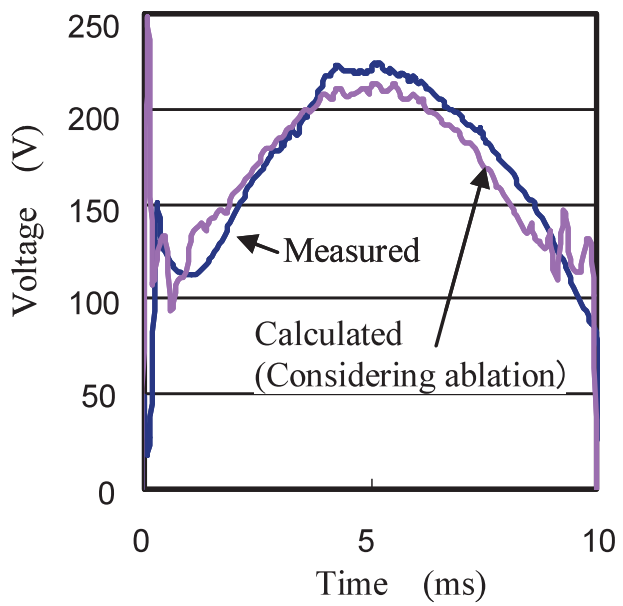

図 6 アーク電圧変化の解析と実測との比較 Fig.6. Comparison of calculated arc voltage with measured. 


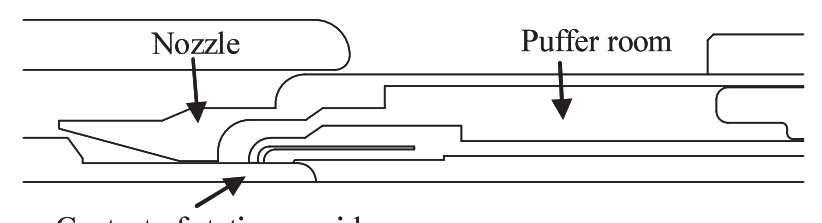

Contact of stationary side

図 7 小型モデル概形

Fig. 7. Outline of interrupter model.

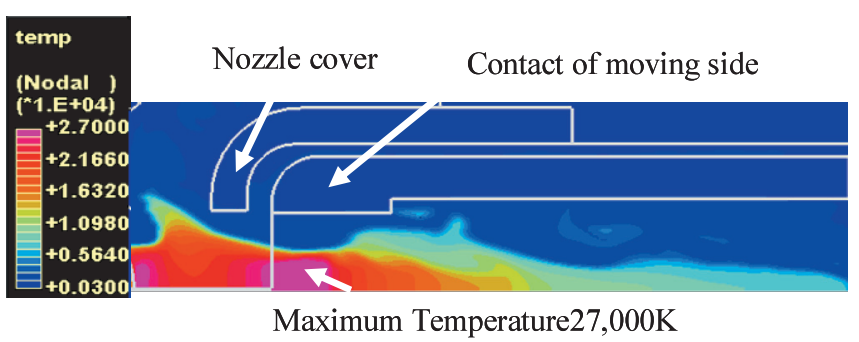

図 8 遮断前 $5 \mathrm{~ms}$ 近傍でのアークの温度分布

Fig. 8. Temperature distribution of arc $5 \mathrm{~ms}$ before current zero.

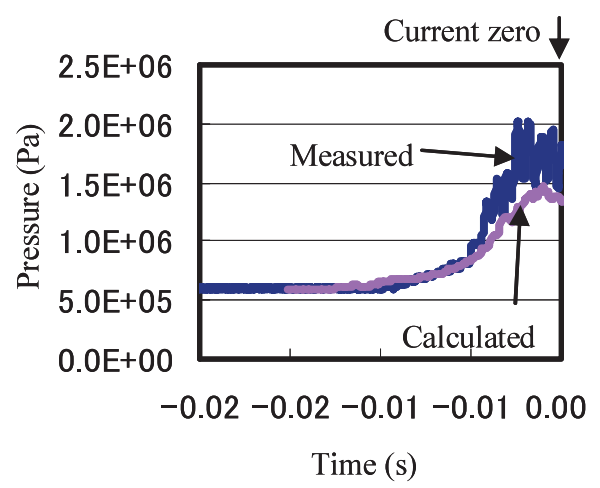

図 9 バッファ室圧力変化

Fig. 9. Change of pressure in puffer room.

定部近傍での圧力および電圧の解析值は, 実測とほぼ一致 している。以上のように，アブレーションの量はアークの 輻射エネルギーと関連付けて見積もることができる。

$\langle 3 \cdot 2\rangle$ 小型モデル遮断実験との比較 図 7 は実器の 小型モデル遮断器の遮断部を示したものである。これに， ピーク值 $10 \mathrm{kA}$ の電流を流した遮断試験についてテスト計 算を実施した。通電時間は半波長の $10 \mathrm{~ms}$ である。可動子 のストロークは別途動作解析を行って与えた。尚，解析に 使用したメッシュ数は約 $1000 \times 160$ で，また，メッシュ幅 は計算の効率を考慮して $0.25 \mathrm{~mm} \sim 1.0 \mathrm{~mm}$ を用いた。図 8 は遮断前 $5 \mathrm{~ms}$ のときのアーク近傍の温度分布, 図 9 はパッ ファ室圧力についての実測との比較, 図 10 はアーク電圧の 比較を示す。図 9 及び図 10 の横軸の時刻は遮断点で時刻 0 である。図 8 に示すように,ノズルカバーからの蒸発により アークがノズルカバーに接触することなく離れている様子 が計算されている。また，このときの最高温度は $27,000 \mathrm{~K}$ であった。パッファ室圧力は低めに予測しているが，計測

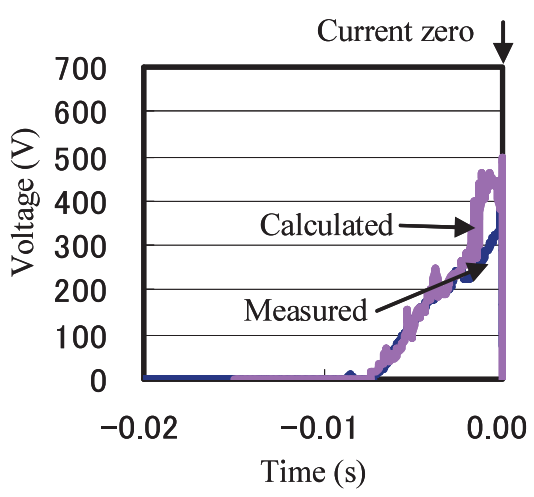

図 10 アーク電圧の変化

Fig. 10. Change of arc voltage.

時の圧力振動の下側の包絡線に一致しており, 計算結果は 妥当と考えられる。アーク電圧は消弧ピークを高めに予測 しているが，全体的には概ね一致している。以上のように 実機遮断器のようにパッファ室と可動アーク接触子から構 成される場合にも本手法が有効であることが確認できた。

\section{4. まとめ}

遮断器内の物理現象を理解するため, アークを考慮した 気流解析技術を開発した。本技術の特徴を下記に示す。

（1）アーク解析でのエネルギー及び密度変動に対し, 数 值的な安定化を図るため, 内部エネルギーの輸送方程式の 変わりに内部エネルギーと密度の積についての輸送方程式 を用いた。

（3）アブレーションの効果を取り入れる方法として, ア ブレーション量は壁面の輻射エネルギー射出率と空間での 輻射強度の差に比例するとした。

（3）電場，圧力場，及び輻射場の連立方程式解法に用 いている PCG 法に一段回のガウス掃きだし法を適用した 未知数を削減する改良を行った。

本手法をアブレーション測定試験と，小型モデルによる 電流遮断実験に適用し, 実験結果と比較したところ, 概ね 実測值を再現でき，本手法が有効であることが分かった。 (平成 18 年 10 月 3 日受付, 平成 19 年 2 月 9 日再受付)

\section{文献}

(1) T. Mori, K. Iwamoto, T. Nakamoto, and K. Suzuki: "Development of gas flow simulation method considering ablation for GCB chamber", SP-99-86 (1999) (in Japanese)

森正・岩本勝治・中本哲哉・鈴木克己 :「アブレーションを考慮 した GCB 消弧室内ガス流解析手法の開発」, 電気学会開閉保護高電 圧合同研資, SP-99-86 (1999)

(2) M. Koizumi, R. Ando, H. Urai, N. Yaginuma, M. Tsukusi, and I. Harada: "Development of a numerical calculation method for arc behavior considering absorptive power of SF6 gas in thermal radiation", T. IEE Japan, Vol.121-B, No.12, pp.1652-1659 (2001-12) (in Japanese)

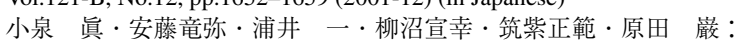
「ガスの輻射吸収性を考慮したアーク挙動解析手法の開発」, 電学論 B, 121, 12, pp.1652-1659 (2001-12)

(3) 堀之内克彦:「ガス遮断器におけるアークシミュレーション技術」, 三 菱電機技報, Vol.80, No.7, pp.7-10 (2006)

(4) A. Gleizes, J.J. Gonzalez, and P. Freton: "Thermal plasma modeling", $J$. 
Phys. D: Appl. Phys., Vol.38, pp.R153-R183 (2005)

(5) T. Yabe, F. Xiao, and T. Utsumi: "The Constrained Interpolation Profile Method for Multiphase Analysis", J. Comp. Phys., Vol.169, pp.556-593 (2001)

（6） 小国 力・村田健郎·三好敏郎・J.J. ドラカン・長谷川秀彦：行列計 算ソフトウェア一WS，スーパーコン，並列計算機一, 丸善 (1991-11)

(7) M. Claessents, K. Moeller, and H.G. Thiel: "A computational fluid dynamics simulation of high- and low-current ares in self-blast ciucuit breakers", J. Phys. D: Appl. Phys., Vol.30, pp.1899-1970 (1997)

(8) M. Koizumi, H. Urai, Y. Ohsita, N. Osawa, J. Kida, and M. Hirose: "Gas flow analysis considering ablation of nozzle material", 2005 National Convention Record IEE Japan, 6-209 (2005) (in Japanese)

小泉 眞 · 浦井 一. 大下陽一 · 大澤直樹 · 木田順三 · 廣瀬 誠 「輻射吸収性によるノズル材蒸発を考慮した気流解析」, 平成 17 年電 気学会全国大会講演論文集, 6-209 (2005)

(9) F. Xiao, T. Yabe, G. Nizam, and T. Ito: "Constructing a multi-dimensional oscillation preventing scheme for the advection equation by a rational function", Comput. Phys. Commun., Vol.94, pp.103-118 (1996)

\section{小泉}

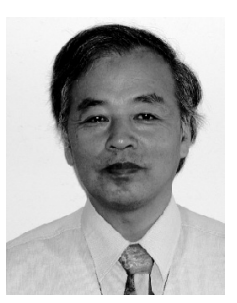

\section{畺} (正員) 1949 年 10 月 15 日生。1975 年 3 月大阪 大学大学院工学研究科原子力工学専攻修士課程修 了。同年 4 月（株）日立製作所日立研究所入所。 同エネルギー研究所, 同電力・電機開発本部を経 て, 現在同電力・電機開発研究所に勤務。主とし て, 電磁気及び熱流体に関する数值解析の研究に 従事。工学博士。

浦 井

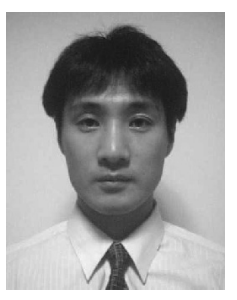

一 (正員) 1968 年 4 月 12 日生。1997 年 3 月東京 工業大学理工学研究科博士課程修了。同年 4 月 (株) 日立製作所電力・電機開発本部入所。現在 同電力・電機開発研究所に勤務。主としてガス遮 断器の研究開発に従事。工学博士。IEEE 会員。

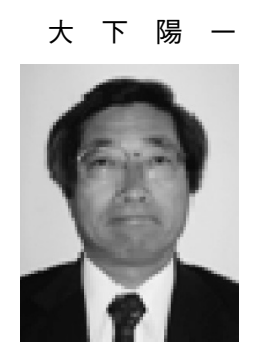

大 澤 直 樹

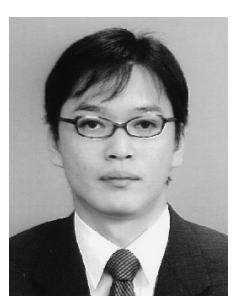

(正員) 1977 年 12 月 29 日生。2004 年 3 月金沢 工業大学大学院工学研究科電気電子工学専攻博士 後期課程修了。同年 4 月（株）日立製作所入社。 現在, 電力. 電機開発研究所にて, 電力用ガス遮断 器に関する研究・開発に従事。博士 (工学)。IEEE 会員。

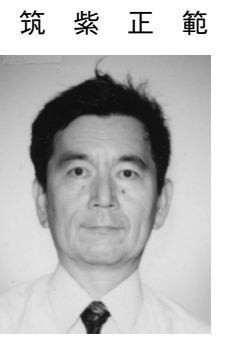

(正員) 1945 年 7 月 11 日生。 1970 年 3 月横浜 国立大学大学院工学研究科電気工学専攻修士課程 修了。同年 4 月 (株) 日立製作所入社日立研究所 にてガス遮断器の遮断部, 遮断現象の研究開発に 従事。1997 年 2 月同社国分工場転属。現在, (株) 日本 $\mathrm{AE}$ パワーシステムズ研究開発本部勤務。工 学博士。

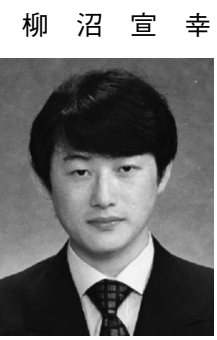

(正員) 1967 年 1 月 19 日生。1992 年 3 月茨城 大学大学院工学研究科修士課程修了。同年 4 月 (株) 日立製作所日立研究所入所。主に, ガス遮 断器遮断部開発等に従事。1997 年 2 月同社国分 工場転属。現在, (株) 日本 $\mathrm{AE}$ パワーシステム ズ開閉装置事業部勤務。 